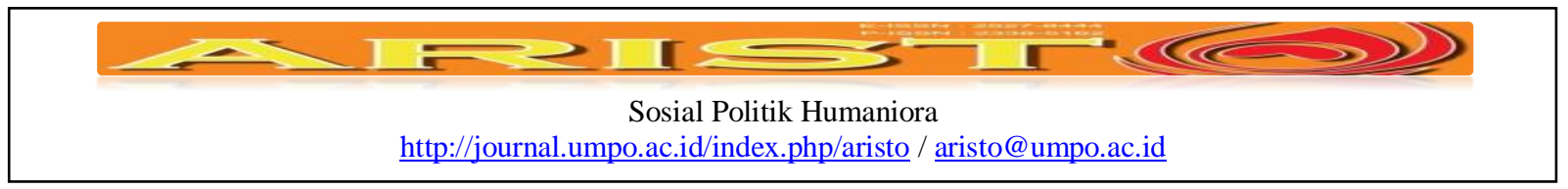

\title{
Model Manajemenkelompok Usaha Mikro Kecil dan Menengah (UMKM) Usaha Tepung Tapioka
}

\author{
Salahudin, Wahyudi, Ihyaul Ulum, Yudi Kurniawan \\ Program Studi Ilmu Pemerintahan, Universitas Muhammadiyah Malang \\ Program Studi Sosiologi, Universitas Muhammadiyah Malang \\ Program Studi Ilmu Pemerintahan, Universitas Muhammadiyah Malang \\ Peneliti Laboratorium Ilmu Pemerintahan, Universitas Muhammadiyah Malang \\ salahudinmsi@umm.ac.id
}

\begin{abstract}
Micro Small and Medium Enterprises (MSMEs) is a buffer of the national economy that it proved able to survive during the monetary crisis in Indonesia in 1997-1998. On the one hand, MSMEs have a strong resilience to the economic crisis. On the other hand, the development of MSMEs is faced with complex problems. This research departs from the complexity of the problems faced in developing Tapioca Starch business. This study aims to understand the problems faced by SMEs in developing Tapioca Flour Business in Kediri and prepare concrete steps to solve the problem. This research used descriptive qualitative method with data collection technique of interview, observation, and documentation. The results of this study indicated that the problems faced by the Tapioca flour business in Kediri are that they have no the formation of the business in a business group, the lack of human resources skills in developing the business, the limited business capital, and the dependence of the entrepreneurs on the middlemen directly and not to the detriment of entrepreneurs. The steps proposed for such issues include the formation of business groups, strengthening cooperative networks with business groups, markets, and cassava growers, and strengthening venture capital through saving and loan systems.
\end{abstract}

Keyword : Business Group, Policy, Empowernment, Society

\begin{abstract}
Abstrak
Usaha Mikro Kecil dan Menengah (UMKM) merupakan penyangga perekonomian nasional yang terbukti mampu bertahan pada saat krisis moneter di Indonesia pada 1997-1998. Di satu sisi, UMKM memiliki ketahanan yang tangguh terhadap krisis perekonomian. Namun di sisi lainnya, pengembangan UMKM dihadapkan dengan berbagai persoalan yang cukup kompleks. Penelitian ini berangkat dari kompleksitas persoalan yang dihadapi dalam mengembangkan usaha Tepung Tapioka. Penelitian ini bertujuan untuk memahami persoalan yang dihadapi UMKM dalam mengembangkan Usaha Tepung Tapioka di Kediri serta menyiapkan langkah- langkah konkret untuk menyelesaikan persoalan tersebut. Penelitian ini menggunakan metode kualitatif deskriptif dengan teknik pengumpulan data wawancara, observasi, dan dokumentasi. Hasil penelitian ini menunjukkan bahwa masalah-masalah yang dihadapi oleh pengusaha Tepung Tapioka di Kediri di antara nya adalah belum terbentuknya usaha tersebut dalam suatu kelompok usaha, minimnya keterampilan SDM dalam mengembangkan usaha, keterbatasan modal usaha, dan ketergantungan para pengusaha terhadap tengkulak yang secara langsung maupun tidak justru
\end{abstract}




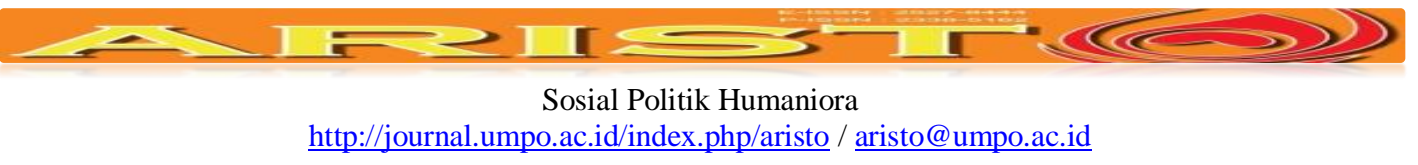

merugikan para pengusaha. Langkah-langkah konkret yang diusulkan atas masalah-masalah tersebut di antara nya yaitu pembentukan kelompok usaha, penguatan jaringan kerja sama dengan kelompok usaha, pasar, dan petani ketela pohon, dan memperkuat modal usaha melalui sistem simpan pinjam.

Keyword: UK4KM, Kelompok Usaha, Kebijakan, Pemberdayaan, Masyarakat.

\begin{tabular}{|ll|}
\hline Submite & $:$ 5 September 2017 \\
Review & $:$ 20 November 2017 \\
Accepted & $:$ 01 Januari 2018 \\
Surel Corespondensi & $:$ hayat@unisma.ac.id \\
\hline
\end{tabular}

\section{Pendahuluan}

Indonesia merupakan produsen tapioka terbesar kedua setelah Thailand dengan total produksi mencapai 3.877.100,4 ton pada tahun 2004 (BPS, 2004), salah satu olahan industri yang banyak diproduksi adalah untuk tepung tapioka (Somaatmaja, 2004). Salah satu wilayah yang telah berhasil mengembangkan agroindustri tapioka skala kecil dan menengah adalah Kabupaten Kediri, yang mencapai 207 unit industri kecil dengan nilai investasi sebesar 4.216 juta rupiah, nilai bahan baku produksi 10.107 juta rupiah dan nilai produksi 7.372 juta rupiah (Wijana, Nurika, dan Habibah, 2009, hal. 97).

Sebagian besar produk tapioka olahan UMKM di Kabupaten Kediri digunakan sebagai bahan baku industri krupuk yang mencapai 267 unit di Kediri, dan sisanya dijual dipasar regional yaitu di sentra industri kerupuk Tulungagung, Surabaya, dan Sidoarjo (Nurika, Deoranto, dan Indriasari, 2017 Wijana dkk, 2009, hal. 97).

Bahan dasar tepung tapioka adalah ketela pohon yang banyak ditanam dikebun - kebun warga, di Kabupaten Kediri. Sekitar 12 Kecamatan merupakan sentra tanaman ketela pohon yaitu Kecamatan Kandat, Kecamatan Ngadiluwih, Kecamatan Ringinrejo, Kecamatan Wates, Kecamatan Plosoklaten, Kecamatan Kras, Kecamatan Mojo, Kecamatan Kandat, Kecamatan Semen dan Kecamatan Banyakan (Badan Ketahanan Pangan dan Pelaksana Penyuluh (BKP3) Kabupaten Kediri, 2017). Ketersediaan ubi kayu di Kabupaten Kediri tiap tahun 30.491,50 ton (Nurika dkk, 2007).

Desa Bulusari Kecamatan Tarokan adalah saíah satu desa di Kabupaten Kediri yang memiliki segudang potensi yang harus terus digali dan dikembangkan. Desa ini dijuluki sebagai Kampung Krupuk karena sebagaian besar warganya memproduksi krupuk dan menjadikannya mata pencaharian utama. Sentra tepung tapioka selain di Desa Bulusari dan Desa Purworejo, 


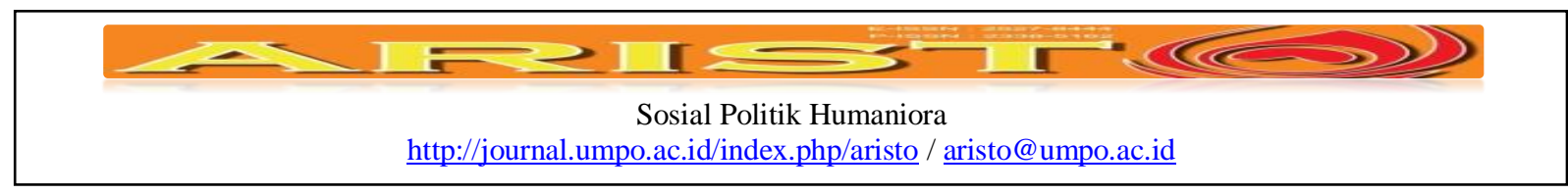

Desa Bulu adalah salah satu desa di Kecamatan Semen Kabupaten Kediri juga memproduksi tepung tapioka dari bahan baku ketela pohon. Produksi tepung tapioka di Desa ini sudah berlangsung lama yaitu sejak tahun 1980 hingga saat ini. Sebagian besar masyarakat di desa ini terlibat dalam usaha produksi tepung tapioka dengan berbagai bidang pekerjaan seperti pengupasan ketela pohon, penggilingan ketela pohon, dan pengeringan sari ketela pohon. Pada awalnya produksi tepung di desa ini berlangsung secara tradisional yakni dilakukan dengan tanpa menggunakan mesin. Pada saat itu produksi tepung tapioka dilakukan dengan alat tradisional seperti pengupasan kulit singkong dilakukan dengan pisau dapur, dan penggilingan ketela pohon dilakukan dengan pamt manual.

Seiring kemajuan jaman, produksi tepung tapioka di Desa Bulu mengalami kemajuan yakni proses produksi tepung tapioka dilakukan dengan mesin. Mesin yang digunakan adalah mesin disel. Sejatinya mesin disel bukan diperuntukkan untuk produksi tepung namun dipemntukkan sebagai mesin pengangkat air dari kali untuk menyirami tanaman pertanian. Namun masyarakat khususnya pengusaha tepung di desa bulu mendesain (merakit) mesin tersebut hingga dapat digunakan sebagai mesin penggilingan ketela pohon (produksi tepung).

Kendati saat ini pengusaha tepung tapioka di desa bulu sudah menggunakan mesin dalam proses produksinya, dan mampu memproduksi tepung tapioka dalam jumlah yang cukup banyak, namun pengusaha tepung tapioka di desa ini masih menghadapi sejumlah permasalahan. Pada bagian analisis situasi ini, kami mengelompokkan persoalan tersebut dalam dua aspek yaitu aspek manajemen dan aspek produksi. Kedua aspek tersebut dijelaskan sebagai berikut.

Pertama, masalah pada bagian manajemen yaitu belum terlembaganya usaha dalam bentuk organisasi, dan minimnya pemahaman para pengusaha tentang perluasan dan keberlanjutan usaha tepung tapioka. Pertama, meskipun usaha pengelolaan tepung tapioka di desa ini sudah berlangsung lama sebagimana dijelaskan pada awal tulisan ini, namun produksi tepung tapioka di desa ini masih dilakukan secara tradisional. Mereka belum terlembaga dalam bentuk organisasi usaha. Karena itu, para pengusaha mengalami kesulitan untuk mengembangkan usaha ini menjadi lebih maju. Sebaiknya dalam pengelolaan usaha harus dinaungi oleh lembaga atau organisasi usaha. Melalui lembaga atau organisasi usaha, para pengusaha terlindungi dari segi administrasi, pengusaha dapat dengan mudah mendapatkan pinjaman modal untuk mengembangkan usaha, dan pengusaha dapat menjadikan organisasi usaha sebagai sarana komunikasi dan interaksi dengan pengusaha tepung, petani ketala pohon, 


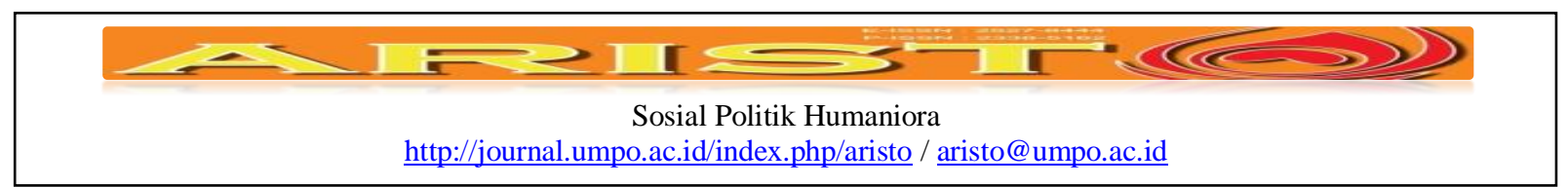

pemerintah, dan pasar (Indrika, 2013; Hermanto dan Swastika, 2011).

Kedua, masalah lain yang dihadapi pengusaha tepung tapioka di desa bulu adalah minimnya pemahaman mereka tentang pengembangan usaha.Berdasarkan hasil observasi, para pengusaha dinilai tidak memiliki wawasan dalam mengembangkan usaha menjadi lebih maju. Selama ini mereka tidak pernah berfíkir untuk mengembangkan usaha menjadi lebih berkembang. Mereka hanya memproduksi tepung tapioka dalam bentuk kasar, dan kemudian dijual ke pengusaha lain atau tepatnya disebut para tengkulak. Para pengusaha juga belum memahami kebermanfaatan air limbah dari penyaringan ketela yang digiling. Bagi para pengusaha air limba tersebut tidak memiliki fungsi karena itu mereka menjualnya dengan harga murah kepada pengusaha tengkulak.

Hasil pengamatan dan kajian yang dilakukan oleh kami menunjukkan bahwapara pengusaha mikro tepung tapioka di Desa Bulu bekerja dengan model manajemen yang dijelaskan di atas sehingga membuat mereka mengalami kerugian materi dan tenaga. Justru para tengkulak yang membeli tepung tapioka kasar dan air limbah penggilingan ketela dari pengusahapengusaha mikro tepung tersebut lebih diuntungkan. Hal ini menunjukkan bahwa tengkulak berada pada posisi yang menguntungkan dan mampu menciptakan ketergantungan para petani terhadap kehadirannya (Fuad, Ainurofik, dan Rosyid, 2015).

Selanjutnya, berdasarklan hasil observasi dan identifíkasi yang dilakukan oleh kami menunjukkan bahwapengusaha tepung tapioka di desa bulu juga menghadapi masalah pada aspek produksi yakni pada bagian sarana produksi, dan terbatasnya penyediaan'pasokan ketala pohon. Pertama, minimnya sarana produksi. Masalah yang dihadapi para pengusaha dalam proses produksi tepung tapioka adalah minimnya sarana pendukung produksi yaitu sarana pengiringan. Selama ini pengusaha tepung di desa ini mengandalkan sinar matahari sebagai sarana pengeringan. Karena itu, pengusaha pengelolaan tepung tidak dapat memproduksi tepung secara maksimal jika musim hujan tiba. Kedua, terbatasnya penyediaanpasokan ketela pohon. Tersendatnya pasokan bahan baku ketela serta sulitnya proses pengeringan tepung tapioka di saat musim hujan tiba, membuat sejumlah pengusaha bahan baku krupuk di Desa Semen Kabupaten Kediri terpaksa 'gulung tikar'. Penyebabnya, pasokan bahan baku ketela tersendat, dan sulitnya proses pengeringan tepung tapioka.

Permasalahan pengusaha mikro tepung tapioka pada kedua aspek di atas (aspek manajemen dan aspek produksi) adalah dinilai sebagai masalah-masalah krusial yang 


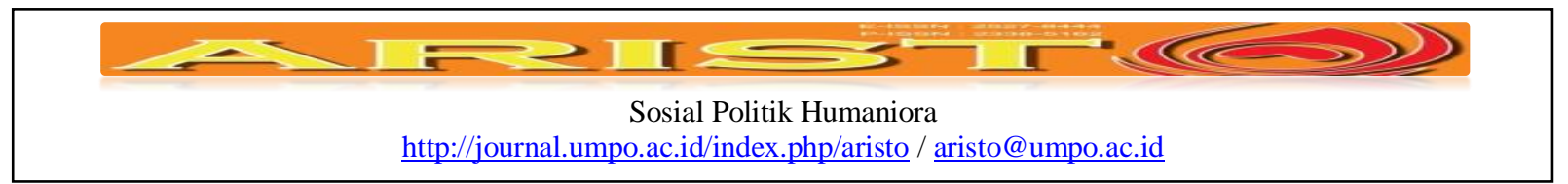

menghambat berkembangnya usaha tepung tapioka di Kabupaten Kediri menjadi lebih maju. Sesungguhnya, permasalahan yang dihadapi oleh pengusaha tepung tapioka di Desa Bulu Kediri seperti yang dijelaskan di atas juga terjadi pada usaha kecil lainnya di berbagai daerah. Syariifah (2015) mengungkapkan bahwa masalah yang paling dominan ditemukan adalah masalah modal usaha. Selain itu, dalam beberapa kasus ditemui jika sebagian pelaku UMKM cenderung tidak menambah modal usahanva untuk mengembangkan bisnis mereka. Pemilik usaha cenderung enggan untuk menambah modal karena mereka sudah merasa puas, dan hal inilah yang membuat kondisi usaha mereka menjadi stagnan (Trenggana, Masodah, dan Pribadi, tt).

Selain modal usaha dan keengganan pelaku usaha mengembangkan bisnisnya, ada beberapa hal lainnya yang menghambat kemajuan UMKM. Nugraheni (t.t) menemukan bahwa pelaku UMKM sendiri masih banyak menghadapi berbagai macam kendala seperti pengolahan, pengemasan, pemasaran, kualitas produk, sumber daya manusia dan keuangan. Temuan tersebut menunjukkan bahwa UMKM belum didukung dengan kemampuan manajemen yang efektif dan efísien.

Temuan lain oleh Rapini, Farida, dan Adji (2016) menyebutkan bahwa faktor-faktor yang menghambat perkembangan UMKM diantaranya yaitu tidak adanya kemauan dari pelaku usaha untuk berkembang, usaha tersebut hanya sebagai usaha sampingan, adanya ketergantungan pada jaringan pemasaran yang sudah ada, serta keterbatan SDM yang tertarik untuk bekerja di usaha tersebut. Hambatan-hambatan tersebut mengindikasikan bahwa masyarakat terkesan kurang tertarik dengan pekerjaan pada sektor infonnal melalui pengembangan UMKM. Dengan demikian, persoalan-persoalan UMKM secara umum berdasarkan temuan-temuan di atas yaitu persoalan manajemen, rendahnya ketertarikan masyarakat terhadap UMKM, dan keterbatasan keterampilan dan pengetahuan SDM dalam mengembangkan UMKM.

Selain itu, Hadi (2015) mengungkapkan bahwa pemberdayaan UKM kota Kendal dalam rangka MDGs 2015 menghadapi permasalahan meliputi keterbatasan kualitas SDM pelaku UKM ditandai dengan minimnya pelaku UKM yang berpendidikan tinggi, akses terhadap sumberdaya produktif seperti keterbatasan permodalan dan akses teknologi, masalah infrastruktur, seperti pasar yang representatif dan sarana jalan yang memudahkan bagi UKM untuk menjual hasil usahanya, dan masalah birokrasi pemerintah, seperti kualitas dan kuantitas sumberdaya aparatur pemerintah dalam pembinaan dan pendampingan bagi UKM. 


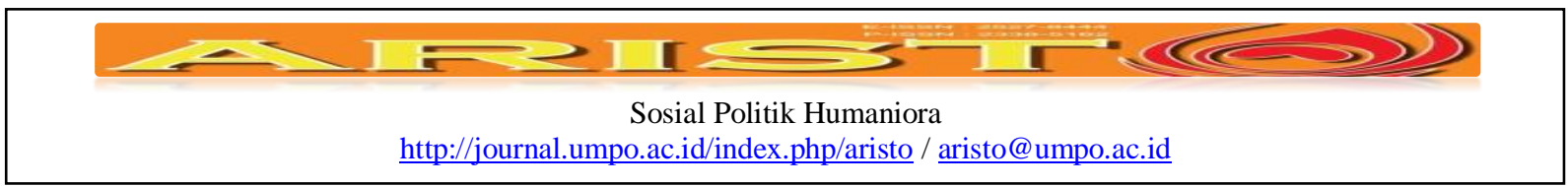

Karena itu, dalam kajian ini, kami mengkaji lebih jauh masalah-masalah yang dihadapi Usaha Mikro Kecil dan Menengah (UMKM) tepung tapioka di desa Bulu Kabupaten Kediri. Kajian ini bertujuan untuk mengetahui masalah-masalah yang dihadapi pengusaha tepung tapioka dalam menjalankan usahanya dan untuk mendesain model pengembangan usaha tepung tapioka di Desa Bulu Kabupaten Kediri.

\section{Metode dan Kajian Pustaka}

Penelitian ini adalah penelitian kualitatif deskriptif yakni menggambarkan kondisi Usaha Mikro dan Kecil Menengah (UMKM) tepung tapioka di Desa Bulu Kabupaten Semen. Teknik pengumpulan data adalah wawancara yaitu peneliti melakukan wawancara langsung kepada pengusaha tepung tapioka, pengepul ketala pohon, dan tokoh-tokoh masyarakat di Desa Bulu Kabupaten Kediri. Kami melakukan wawancara langsung dengan pengusaha tepung tapioka yakni Suwandi, Sumarno, Rudi, Bustomi, Imam, dan Yayin. Kami mendapatkan informasi yang lengkap tentang kapasitas mereka dalam menjalankan usaha tepung tapioka. Selain teknik wawancara, kami juga melakukan pengumpulan data melalui kegiatan observasi dan dokumentasi aktifitas pengusaha tepung tapioka di Desa Bulu.

Selanjutnya, kami juga telah melakukan diskusi dan pertemuan dengan para pengusaha tepung tapioka guna menggali informasi tentang aktifitas usaha mereka. Pertemuan dan diskusi berlangsung secara intensif di sekretariat kelompok usaha. Melalui pertemuan dan diskusi tersebut, kami mendapatkan informasi yang mendukung data-data hasil wawancara sebelumnya. Penelitian ini dilakukan selama delapan bulan yakni mulai bulan Januari hingga Agustus 2017. Dalam waktu delapan bulan, kami mendapatkan data-data penelitian, baik data primer maupun data sekunder.

Data-data tersebut dianalisis melalui pendekatan pendekatan Creswell (2013) yakni, manajemen data (mengorganisasikan memoing data (refleksi dan menulis catatan), deskripsi, klasifikasi dan penafsiran data (kategori dan perbandingan data), penyajian dan visualisasi data. Berangkat dari masalah tersebut, kami mendesain model manajemen usaha tepung tapioka, yaitu manajemen yang berbasiskan penguatan lembaga usaha, penguatan jejaring usaha, dan penguatan modal usaha. Sinergisitas tigak aspek tersebut dipercayai mampu mewujudkan usaha tepung tapioka yang berdaya saing. 


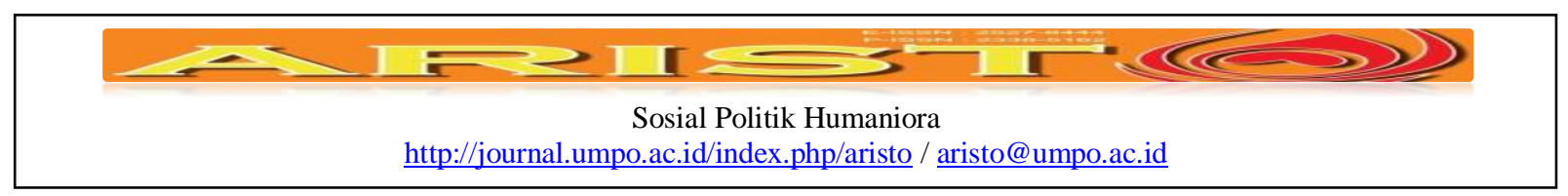

\section{UMKM dalam Perspektif Ekonomi Keynesian}

Pemikiran ekonomi Keynes lahir sebagai kritik atas pandangan ekonomi klasik yang memandang peran pemerintah perlu dibatasi karenapasar dianggapmemiliki fungsiself regulating. Menanggapi krisis ekonomi Great depression 1930-an, Keynes menyatakan self regulating ekonomi klasik gagal berfungsi sehingga diperlukan peran pemerintah untuk mengatasi kegagalan tersebut dengan kebijakan stabilisasi(Ediarno, 2015:11).Selain itu, teori ekonomi Keynessekaligus mengkritik pandangan Karl Marx yang menolak kepemilikan pribadi atas alat produksi dan sistem perekonomian yang hanya berorientasi profit.

Baik ajaran Adam Smiths tentang kapitalisme bebas dengan seminimal mungkin intervensi negara maupun penolakan Karl Marx terhadap persaingan dan kepemilikan pribadi atas alat produksi, ternyata bermasalah (Vaut dkk, 2014:25).Keynes menganggap peran pemerintah perlu dalam pembangunan.Pendekatan Keynesian mengasumsikan adanya price rigidity dan excess capacity sehingga output ditentukan oleh permintaan agregat (demand driven). Keynes juga menyatakan bahwa dalam kondisi resesi, perekonomian yang berbasis mekanisme pasar tidak akan mampu untuk pulih tanpa intervensi dari Pemerintah(Surjaningsih, Utari, dan Trisnanto, 2012:393).

Dalam masa kesulitan ekonomi, negara harus mengintervensi pasar dan menaikkan permintaan lewat pengambilan utang dan peningkatan belanja (Vaut dkk, 2014:25). Tetapi Keynes melihat bahwa pengaruh ini tidaklah dijalankan melalui pelaksanaan langsung kekuasaan politik, melainkan melalui pengaturan variabeI-variabel ekonomi kunci dan membuka konsekuensi-konsekuensi ekonomi dan pengaturan melalui regulasi pemerintahan(Handoko, 2013:70).

Berdasarkan pendekatan keynesian tersebut, peran pemerintah mendukung UMKM merupakan representasi intervensi pemerintah untuk melindungi golongan usaha mikro, kecil, dan menengah. Demi mendukung dan meningkatkan produktivitas UMKM, pemerintah menyusun Rencana Pembangunan Jangka Panjang Nasional (RPJPN) tahun 2005-2025 yang berisi kerangka berpikir pemberdayaan Koperasi dan UMKM. Kerangka berpikir ini menunjukkan pemberdayakan UMKM diperlukan sejumlah prasyarat terencana, sistematis, dan menyeluruh yang meliputi: (1) penciptaan iklim usaha dalam rangka membuka kesempatan berusaha seluas-luasya dan menjamin kepastian usaha disertai adanya efisiensi ekonomi; (2) pengembangan sistem pendukung usaha bagi UMKM untuk meningkatkan akses sumber daya 


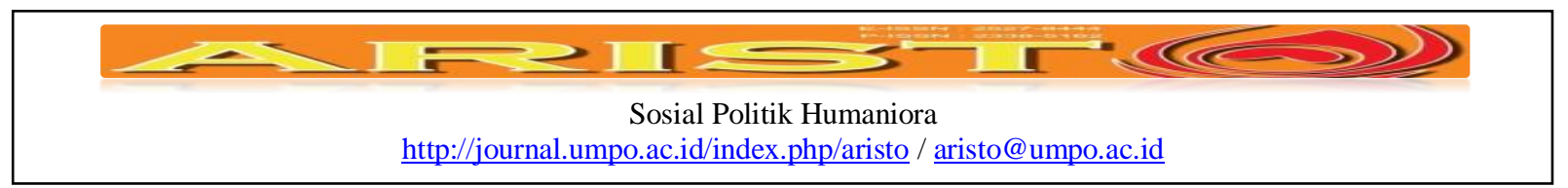

produktif sehingga dapat memanfaatkan kesempatan yang terbuka dan potensi sumber daya, terutama sumber daya lokal(Fitriati, 2015:4).

Selain itu, UU No. 20 tahun 2008 tentang Usaha Mikro Kecil dan Menengah memberi mandat kepada Pemerintah Pusat dan Daerah untuk menumbuhkan iklim usaha khususnya melalui fasilitasi pendanaan bagipelaku UMKM. Hal ini mencerminkan bahwa pemerintah memiliki peran penting untuk mendukung pasar agar terhindar dari krisis jangka pendek maupun panjang. Keynes melakukan reposisi hubungan ekonomi dengan politik, dengan memasukkan kebijakan pemerintah (stabilization policy) sebagai salah satu variabel ekonomi yang penting dan bahkan lebih powerful(Ediarno, 2015:11).

Daya tahan Usaha Mikro Kecil dan Menengah (UMKM) dalam menghadapi krisis ekonomi yang terjadi di Indonesia pada 1997-1998 berkontribusi terhadap stabilitas perekonomian nasional. Hadiwijoyo (2014) menyebutkan tiga faktor yang mendukung UMKM mampu menghadapi krisis ekonomi tersebut.Pertama, UMKM umumnya menghasilkan barang konsumsi dan jasa yang dekat dengan kebutuhan masyarakat. Kedua, pelaku UMKM umumnya memanfaatkan sumber daya lokal, baik itu sumber daya manusia, modal, bahan baku, hingga peralatan. Ketiga, bisnis UMKM umumnya tidak ditopang dari pinjaman bank, melainkan dari dana sendiri.

Namun demikian, di sisi lainnya, UMKM memiliki persoalan yang kompleks sehingga sering mengalami stagnasi dalam pengembangan bisnis yang dijalankan. Bahkan, sumber modal yang berasal dari pelaku UMKM secara mandiri tanpa suntikan dana dari bank sebagai salah satu faktor yang dianggap memperkuat UMKM saat krisis ekonomi 1997-1998 ibarat dua sisi mata pisau. Meskipun UMKM mampu dijalankan dengan dana mandiri, namun pelaku UMKM seringkali dihadapkan dengan modal bisnis yang terbatas.

Adler Heymans Manurung, Direktur Fund Management PT. Nikko Securities, mengatakan bahwa meskipun mengalami pertumbuhan yang bagus, UMKM di Indonesia belum bisa beranjak dari masalah klasik, yaitu modal atau kredit (Disampaikan pada Seminar Pembiayaan UMKM dan Koperasi, 2008). Syariifah (2015) juga mengungkapkan bahwa masalah yang paling dominan ditemukan adalah masalah modal usaha. Selain itu, dalam beberapa kasus ditemui jika sebagian pelaku UMKM cenderung tidak menambah modal usahanya untuk mengembangkan bisnis mereka. Pemilik usaha cenderung enggan untuk menambah modal karena mereka sudah merasa puas, dan hal inilah yang membuat kondisi usaha 


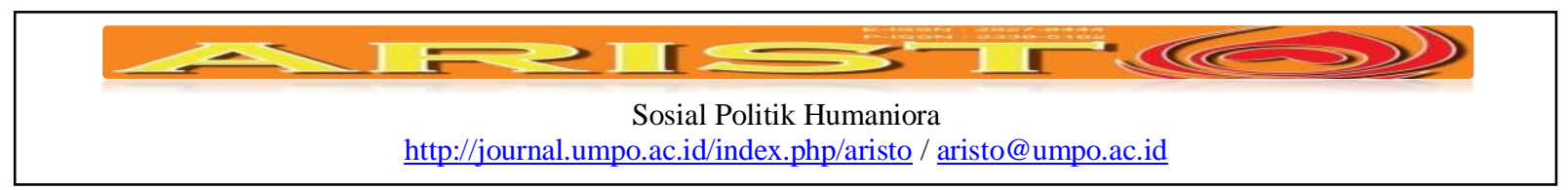

mereka menjadi stagnan (Trenggana, Masodah, dan Pribadi, tt).

Modal usaha merupakan salah satu instrumen penting, baik bagi usaha atau bisnis yang sedang dirintis maupun yang telah berjalan. Afifah dan Setiawan (2012) menemukan bahwa kredit yang diberikan oleh Dinas Koperasi dan UMKM Kota Semarang dapat membantu meningkatkan modal usaha, omzet penjualan, dan laba para pelaku usaha mikro di Kelurahan Pekunden yang dilihat dari perbedaan variabel modal usaha, omzet penjualan, dan laba antara sebelum dan setelah mendapat kredit yaitu modal usaha terdapat kenaikan sebesar 55,87\%, omzet penjualan terdapat kenaikan sebesar 22,22\%, dan kenaikan laba sebesar 44,12\%. Dengan demikian, berdasarkan temuan tersebut, tambahan modal usaha memiliki pengamh positif terhadap peningkatan laba dan omzet penjualan.

Selain modal usaha dan keengganan pelaku usaha mengembangkan bisnisnya, ada beberapa hal lainnya yang menghambat kemajuan UMKM. Nugraheni (t.t) menemukan bahwa pelaku UMKM sendiri masih banyak menghadapi berbagai macam kendala seperti pengolahan, pengemasan, pemasaran, kualitas produk, sumber daya manusia dan keuangan. Temuan tersebut menunjukkan bahwa UMKM belum didukung dengan kemampuan manajemen yang efektif dan efísien. Temuan lain oleh Rapini, Farida, dan Adji (2016) menyebutkan bahwa faktor-faktor yang menghambat perkembangan UMKM diantaranya yaitu tidak adanya kemauan dari pelaku usaha untuk berkembang, usaha tersebut hanya sebagai usaha sampingan, adanya ketergantungan pada jaringan pemasaran yang sudah ada, serta keterbatan SDM yang tertarik untuk bekerja di usaha tersebut. Hambatan-hambatan tersebut mengindikasikan bahwa masyarakat terkesan kurang tertarik dengan pekerjaan pada sektor informal melalui pengembangan UMKM.

Selain itu, Hadi (2015) menemukan bahwa pemberdayaan UKM kota Kendal dalam rangka MDGs 2015 menghadapi permasalahan meliputi keterbatasan kualitas SDM pelaku UKM ditandai dengan minimnya pelaku UKM yang berpendidikan tinggi, akses terhadap sumberdaya produktif seperti keterbatasan permodalan dan akses teknologi, masalah infrastruktur, seperti pasar yang representatif dan sarana jalan yang memudahkan bagi UKM untuk menjual hasil usahanya, dan masalah birokrasi pemerintah, seperti kualitas dan kuantitas sumberdaya aparatur pemerintah dalam pembinaan dan pendampingan bagi UKM.

Dengan demikian, persoalan-persoalan UMKM secara umum berdasarkan temuantemuan di atas yaitu persoalan manajemen, rendahnya ketertarikan masyarakat terhadap UMKM, dan keterbatasan keterampilan dan pengetahuan SDM dalam mengembangkan UMKM. Adapun 


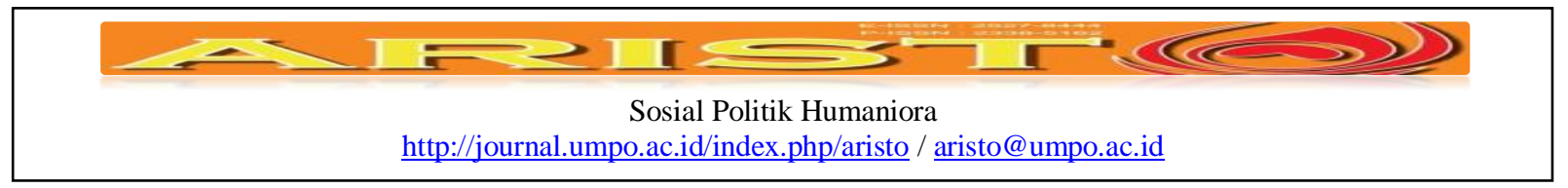

temuan yang menjadi perhatian utama adalah rendahnya peran pemerintah dalam mendukung pengembangan UMKM, baik dalam penyediaan infrastruktur jalan atau pasar maupun pembinaan dan pemberdayaan UMKM.

Pada praktiknya, peran pemerintah khususnya dalam pembinaan dan pemberdayaan tidak serta merta berpengaruh positif terhadap pengembangan UMKM tanpa penyediaan infrastruktur maupun ruang untuk melakukan pemasaran. Kumiawan dan Fauziah (2014) dalam menemukan bahwa penghambat dalam pemberdavaan UMKM adalah infrastruktur yang kurang memadai atau rusak, kurang maksimalnya bantuan dari pemerintah, tidak adanya tempat pembuangan limbah dan tidak adanya sentra pemasaran hasil produksi. Oleh sebab itu, masalah-masalah dalam pengembangan UMKM menjadi semakin kompleks, baik yang berasal dari faktor internal maupun eksternal. Hal ini sekaligus merupakan tantangan bagi para stakeholders untuk meminimalisasi hambatan- hambatan tersebut demi pengembangan UMKM.

\section{Model Pengelolaan UMKM}

\section{Model pengelolaan UMKM di beberapa negara}

Model pengelolaan UMKM di setiap daerah atau negara sangat beragam tergantung pada masalah dan potensi yang dimiliki. Hendrawan (2011) memaparkan bahwasecara umum, Singapura memilih untuk menerapkan model intervensionis dalam pengembangan UMKMnya. Startegi Singapura telah memusatkan perhatian pada meningkatkan teknologi sebagai prioritas tinggi dalam pengembangan UMKM. Dari sisi pembiayaan, kolaborasi antara pemerintah dan sektor swasta digalakkan. Untuk pendirian UMKM, maka penyediaan oleh pemerintah tersedia memadai baik melalui Microloan, SPRING SEEDS, maupun EnterpriseInvesment Incentive. Untuk pengembangan UMKM tersedia Local Enterprice Finance Scheme maupun Growth Financing Scheme. Untuk UMKM yang menuju kancah global disediakan banyak dana diantaranya Internationalization Finance Scheme. Tentu saja dukungan lain seperti edukasi, pameran, dan lain-lain.

Negara lain di Kawasan Asia Tenggara yang sejak lama mengembangkan UMKM adalah Thailand. Sari dkk (2015) memaparkan bahwa Thailand mulai mendorong agar UMKM mempunyai linkage yang kuat pada sektor otomotif mulai tahun 2000 melalui program SME Promotion Plan. Fokus kebijakan tersebut adalah bagaimana meningkatan jumlah tenaga kerja, memperkuat modal UMKM, mendorong ekspor, dan meningkatkan keterkaitan dengan 


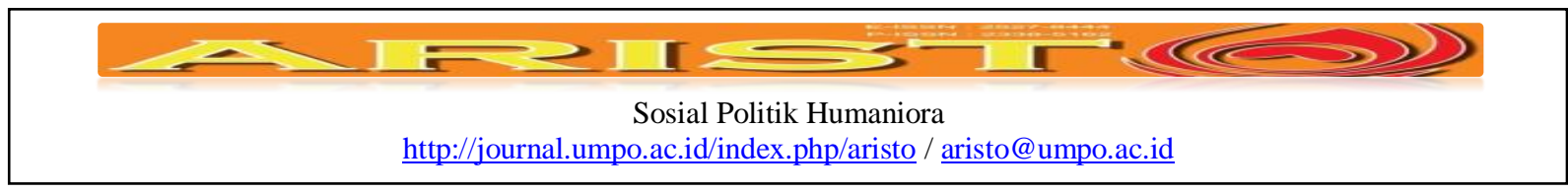

perusahaan besar. Terkait dengan permodalan pada tahun 2002 pemerintah Thailand mendirikan Small and Medium Enterprise Development Bank of Thailand untuk meningkatan dan mempermudah akses finansial UMKM (Caiyuth dalam Sari dkk, 2015).

Bank Indonesia dalam “Kajian Akademik Pemeringkat Kredit Bagi Usaha Mikro, Kecil dan Menengah di Indonesia" tahun 2011 juga memaparkan bahwa di beberapa negara tidak memiliki kementerian khusus menangani masalah koperasi dan UMKM seperti di Indonesia. Namun, pemerintah melalui departemen yang berkaitan dengan perindustrian dan perdagangan memiliki peranan aktif dalam mengembangkan UMKM di negaranya.Peru bahkan memiliki tiga komisi berkaitandengan pengembangan UMKM, yaitu komisi promosi UMKM (PROMPYME), program pengembangan berbasis voucher bagi UMKM (BONOPYME), dan program inovasi teknologi manufaktur sepatu (CITE-Calzado).

\section{Model Pengelolaan UMKM di Indonesia}

Adapun pengelolaan UMKM di Indonesia merupakan tanggung jawab Kementerian Koperasi dan UKM. Dalam rangka mewujudkan pengembangan UMKM di Indonesia, Kementerian Koperasi dan UKM memiliki beberapa strategi. Berdasarkan Rencana Strategis Kementerian Koperasi dan UKM tahun 2015-2019, arah kebijakan dalam rangka mengatasi permasalahanpermasalahan UMKM diantaranya yaitu peningkatan kualitas sumber daya manusia, peningkatan akses pembiayaan dan perluasan skema pembiayaan, peningkatan nilai tambah produk dan jangkauan pemasaran, penguatan kelembagaan usaha, dan kemudahan, kepastian dan perlindungan usaha.

Selain Kementerian Koperasi dan UKM, beberapa lembaga lainnya juga memiliki tanggung jawab untuk mengembangkan UMKM di Indonesia. Sebagai contoh, Bank Indonesia memiliki kebijakan untuk meningkatkan fungsi intermediasi perbankan yang salah satunya bertujuan untuk membantu akses pendanaan bagi UMKM. Kebijakan ini tertuang baik dari sisi penawaran maupun permintaan. Di sisi permintaan, program Bank Indonesia difokuskan pada penguatan lembaga pendamping UMKM dalam bentuk kegiatan pelatihan dan penelitian. Kementerian Keuangan (Kemenkeu) melalui Peraturan Menteri Keuangan (PMK) No. 135/PMK.05/2008 mengeluarkan program penjaminan Kredit Usaha Rakyat (KUR) yang tujuannya mengembangkan UMKM dan koperasi secara berkesinambungan. Peraturan ini kemudian mengalami revisi dalam hal jangka waktu kredit, retstrukturisasi, dan plafon pinjaman dengan dikeluarkannya PMK No.1O/PMK.05/2009 (Bank Indonesia, 2011). 


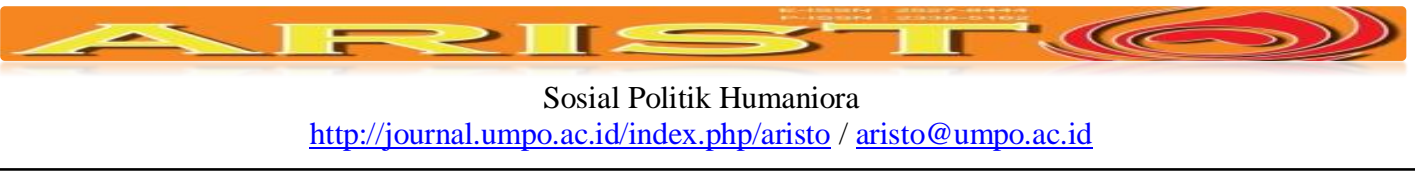

Berdasarkan kebijakan-kebijakan di atas mengindikasikan bahwa pemerintah menyediakan akses pendanaan sehingga UMKM harus terbuka dan tidak tabu terhadap dunia perbankan dalam rangka memperkuat modal usahanya melalui lembaga-lembaga pembiayaan, baik bank maupun non bank. Sudaryanto, Ragimun, dan Wijayanti (t.t) menyebutkan bahwa strategi untuk mengembangkan Usaha Mikro, Kecil, dan Menengah (UMKM) di Indonesia tidak terlepas dari dukungan perbankan dalam penyaluran kredit. Saat ini skim kredit yang sangat familiar di masyarakat adalah Kredit Usaha Rakyat (KUR), yang khusus diperuntukanbagi UMKM dengan kategori usaha layak, tanpa agunan.

Menurut Badan Pengkajian dan Pengembangan Kebijakan Perdagangan Kementerian Perdagangan (2013), akses pembiayaan UMKM lebih banyak diperoleh dari bank umum dibandingkan dengan lembaga pembiayaan seperti koperasi dan lembaga pembiayaan non bank. Namun demikian, dalam skala lokal, eksistensi lembaga pembiayaan non bank seperti koperasi masih menjadi mitra strategis bagi UMKM. Sarwoko (2009) menemukan bahwa Koperasi Simpan Pinjam/Unit Simpan Pinjam memiliki peran yang cukup besar dalam pemenuhan permodalan UMKM di Kabupaten Malang, ditunjukkan dari kemampuan KSP/USP dalam menyalurkan kredit mengalami peningkatan. KSP/USP mampu menyalurkan kredit modal kerja ke UMKM sebesar 79,81\% dari total kredit yang disalurkan. Tingginya kemampuan KSP/USP dalam penyaluran kredit menunjukkan semakin meningkatnya peran KSP/USP dalam pemberdayaan ekonomi rakyat. Oleh sebab itu, berdasarkan data dan temuan di atas, penyediaan pinjaman modal bagi UMKM merupakan langkah strategis untuk mendukung pengelolaan UMKM agar lebih berkembang.

Namun demikian, UMKM yang telah menerima pinjaman atau kredit dalam rangka pengembangan usaha harus tetap dibina dan dipantau. Dengan kata lain, lembaga pembiayaan harus ikut mengawasi dan membina UMKM sehingga dana pinjaman digunakan sesuai peruntukannya. Dalam suatu kasus, Rafki dan Akhirman (tt) menemukan bahwa ketika menerima bantuan dana bergulir hampir semua UKMKmenjawab bahwa mereka sangat membutuhkan tenaga ahli pendamping sebagai konsultan bagaimana memanfaatkan dana bergulir tersebut untuk bisa mengembangkan usaha. Pihak Pemerintah Provinsi Kepri dalam hal ini terkesan hanya memberikan dana secara utuh tanpa mengawasi dan memberikan bimbingan kepada pihak UKM dan Koperasi penerima bantuan tersebut. Hal ini jelas sangat beresiko karena bisa saja dana yang diterima oleh pihak UMKM bisa saja dipakai untuk 


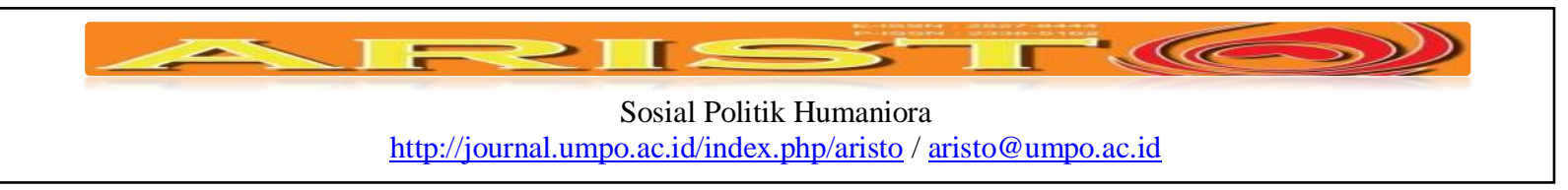

keperluan lain yang tidak bersifat pengembangan usaha.

Selain itu, kualitas SDM dalam pengelolaan UMKM memiliki peran sentral untuk terus meningkatkan daya saing dalam skala lokal, nasional, hingga bahkan internasional. Dengan kata lain, pembinaan dan pemberdayaan terhadap pelaku atau bahkan calon pelaku UMKM perlu dilaksanakan untuk meningkatkan kemampuan dan keterampilan berwirausaha. Strategi pengembangan sumber daya manusia merupakan aspek yang paling penting dalam proses pembangunan ekonomi. Pengembangan kualitas sumber daya manusia dapat dilakukan dengan pelatihan dengan system customized training, yaitu sistem pelatihan yang dirancang secara khusus untuk memenuhi kebutuhan dan harapan si pemberi kerja, pembuatan bank keahlian (skilf banks), sebagai bank informasi yang berisi data tentang keahlian dan latar belakang orang yang menganggur, penciptaan iklim yang mendukung bagi perkembangan lembaga-lembaga pendidikan dan keterampilan di daerah, dan pengembangan lembaga pelatihan bagi para penyandang cacat (Pujiono, 2010). Dengan demikian, kebutuhan UMKM terhadap kualitas SDM yang terampil dapat terakomodasi melalui pengembangan kualitas sumber daya manusia tersebut.

Pengelolaan UMKM di era digital seperti saat ini, penguasaan teknologi informasi khususnya strategi optimalisasi media sosial merupakan suatu kebutuhan untuk mengembangkan atau melakukan ekspansi pasar atas produk-produk yang dihasilkam oleh UMKM. Hal ini perlu dilakukan karena sasaran komunikasi pemasaran produk dan jasa dari UKM sektor informal sudah menggunakan media sosial. Berkaitan dengan hal ini para pelaku UKM dituntut untuk dapat menggunakan aplikasi media sosial seperti website, facebook, twitter, hingga instagram (Kencana, Lestari, dan Nuricahyanti, 2016). Melalui media sosial, kegiatan promosi atau marketing menjadi lebih efektif dan efisien karena dapat menjangkau semua lapisan masyarakat tanpa dibatasi letak geografis. Dengan demikian, hal ini sekaligus dapat memicu UMKM untuk terus berkembang dan memiliki daya saing yang tinggi.

Model kemitraan dalam pengelolaan UMKM merupakan alternatif untuk mendorong UMKM semakin produktif. Kemitraan yang dimaksud dapat dilakukan dengan pihak pemerintah maupun dengan swasta. Model kemitraan dengan swasta dapat dilakukan melalui bantuan atau intervensi pasar oleh pemerintah. Dengan kata lain, pemerintah dapat mengeluarkan kebijakan agar peritel besar seperti hipermarket, supermarket, dan minimarket menyediakan ruang untuk pemasaran produk UMKM. Liana dan Indrianinwum (2008) mengusulkan agar 


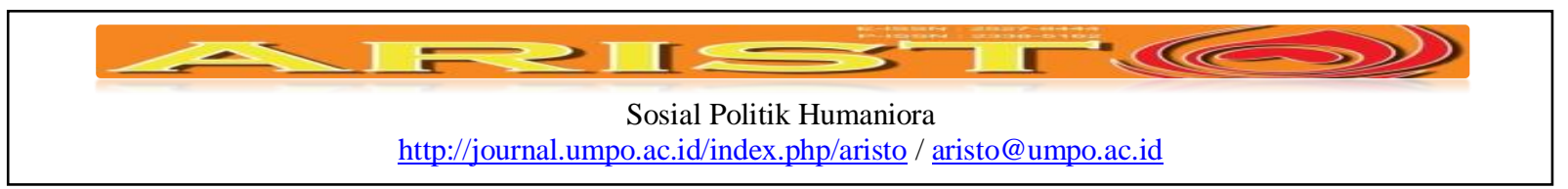

hipermarket, departement store, supermarket dan minimarket yang berdiri sendiri wajib menyediakan tempat usaha untuk UMKM yang mampu dibeli atau disewa atau dapat dimanfaatkan oleh UMKM melalui kerjasama lain dalam rangka kemitraan.

Dengan demikian, perkembangan ritel besar yang pesat tidak akan menggerus UMKM melainkan justru memberi ruang bagi pengembangan UMKM. Selain itu, model kemitraan dapat dilakukan dengan pihak pemerintah khususnya dengan BUMN. Sulistyo dan Adiatma (2011) mengungkap bahwa mekanisme penyaluran bantuan modal dan pembinaan BUMN melalui PKBL (Program Kemitraan dan Bantuan Lingkungan) saat ini ada dua, yaitu BUMN mitra UKM bekerjasama dengan Dinas Koperasi dan UKM untuk menseleksi UKM yang layak diberikan bantuan permodalan (rekomendasi) termasuk persyaratan administrasi dan agunan. Mekanisme kedua dilakukan oleh BUMN mitra UKM secara langsung dan ditangani sendiri, baik kriteria UKM yang dibiayai, persyaratan administrasi serta agunan pinjaman tanpa melibatkan pihak Dinas Koperasi dan UKM.

Besarnya dana kemitraan yang diterima UKM binaan berkisar antara 5- 30 juta. Bantuan modal ini sangat membantu pengembangan usaha UKM, karena selama ini salah satu kelemahan UKM adalah sulitnya akses permodalan karena tidak memiliki jaminan dan tidak bankable. Tingkat pengembalian pinjaman UKM cukup baik yang tercermin dari 89,8\% tidak macet, sementara hanya $10,2 \%$ saja yang macet. Kaitannya dengan peningkatan kualitas manajemen usaha kecil menengah, maka telah dilakukan berbagai pelatihan-pelatihan sebagai upaya untuk meningkatkan ketrarnpilan dan pengetahuan usaha kecil dan menengah. Adapun pelatihan-pelatihan yang telah dilakukan antara lain yaitu kewirausahaan, pemasaran, operasional dan keuangan. Dengan demikian, model kemitraan merupakan alternatif lain dalam rangka pengembangan UMKM agar lebih produktif.

\section{Hasil dan Pembahasan}

Hasil analisis data menunjukkan bahwa terdapat beberapa masalah yang dihadapi oleh pengusaha tepung tapioka di Desa Bulu Kecamatan Semen Kabupaten Kediri, yaitu belum terbentuknya lembaga usaha, minimnya keterampilan SDM dalam mengembangkan usaha, keterbatasan modal usaha permainan tengkulak ketela pohon, dan permainan pengusaha penampung tepung. Masalah-masalah tersebut dipandang sebagai bagian dari persoalan krusial yang menghambat majunya usaha tepung tapioka di Desa Bulu Kediri. Berikut ini dijelaskan 


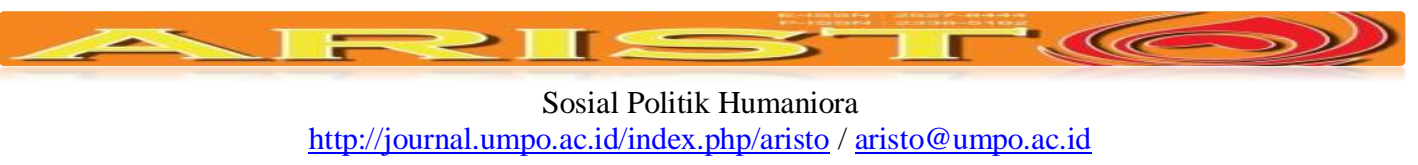

masalah-masalah tersebut.

\section{Masalah-Masalah Pengusaha Tepung Tapioka di Kediri}

\section{Belum terbentuknya lembaga usaha}

Hasil penelitian ini menunjukkan bahwa usaha Tepung Tapioka di Kediri dijalankan secara pribadi dan belum terlembaga dalam suatu kelompok usaha sehingga manajemen usaha belum dijalankan secara profesional. Berdasarkan data wawancara yang dihimpun menunjukkan bahwa usaha tepung tapioka di Desa Bulu Kediri berjalan tanpa organisasi usaha. Hal ini berlangsung sejak usaha tersebut dijalankan pada tahun 1950 hingga saat ini. Misalnya, Suwandi, pengusaha tapioka di Desa Bulu, mengatakan "usaha ini dirintis oleh nenek kakek kami. Dari dulu hingga saat ini, model usaha tetap seperti ini. Kami jalankan usaha ini sendiri-sendiri (wawancara, 12 Juli 2017).

Tentu saja, usaha tanpa organisasi usaha berdampak langsung pada lambatnya perkembangan usaha yang ditekuni. Berdasarkan data observasi dan wawancara menunjukkan bahwa perkembangan usaha tepung tapioka di Desa Bulu tergolong sangat lambat. Hal ini ditunjukkan peralatan yang mendukung usaha mereka masih sangat tradisional seperti peralatan pengeringan sari ketala pohon masih menggunkan anyaman bambu dan mengandalkan sinar matahari. Peralatan konvensional seperti ini berdampak langsung pada lambatnya proses produksi tepung tapioka di desa ini.

Sejalan dengan temuan di atas, Fitrotin (2006)mengatakan bahwa terdapat beberapa hambatan dalam menjalankan wirausaha terutama apabila dijalankan secara pribadi, di antaranya adalah kedisiplinan, keterbatasan modal, penyediaan bahan baku, kerumitan proses produksi, dan pemasaran. Selain itu, pembentukan kelompok usaha memiliki pengaruh terhadap peningkatan etos kerja para anggota kelompok.

Karena itu, harusnya para pengusaha tepung pati di desa ini mulai berfikir untuk membentuk kelompok usaha sebagai sarana bersama dalam mengembangkan usaha ke arah yang lebih maju. Pranata dan Sudarjo (1999) dalam hasil penelitian mereka menemukan bahwa pembentukan kelompok (teambuilding) ternyata menimbulkan etos kerja serta mampu memberikan kontribusi yang cukup besar bagi produktivitas insani.

Berdasarkan temuan tersebut, peningkatan etos kerja melalui pembentukan kelompok usaha akan berkontribusi terhadap pengembangan usaha masyarakat. Peningkatan etos kerja melalui pembentukan kelompok usaha secara tidak langsung juga merupakan upaya bagi masyarakat untuk memberdayakan dirinya sendiri. Andayani (t.t) dalam jurnal berjudul Pemberdayaan Masyarakat rnelalui Kelompok Usaha Bersama (KUBE) menjelaskan bahwa pemberdayaan masyarakat melalui kelompok usaha bersama (KUBE) sangat bermanfaat bagi masyarakat, karena dengan berkelompok 


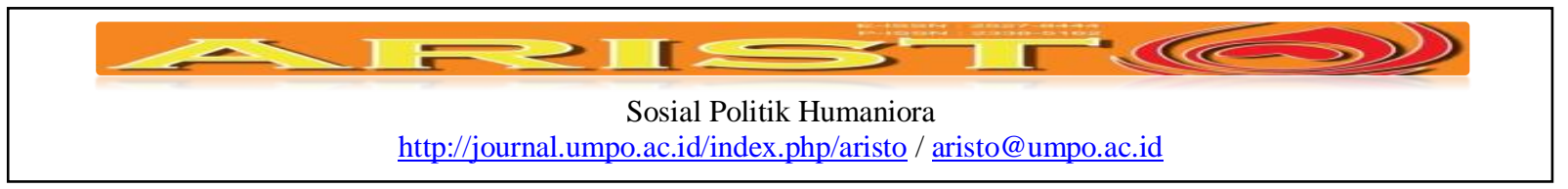

masyarakat akan memiliki wadah dalam melakukan kegiatannya. Dengan demikian, kondisi demikian akan berimplikasi terhadap upaya-upaya para pengusaha dalam mengembangkan usahanya.

\section{Minimnya keterampilan SDM dalam mengembangkan}

Usaha Keterampilan sumber daya manusia dalam mengembangkan usaha memiliki peranan yang sangat penting. Namun, dalam temuan ini, usaha Tepung Tapioka di Kediri dihadapkan dengan rendahnya keterampilan dan pengetahuan sumber daya manusia dalam mengembangkan usaha.

Berdasarkan hasil wawancara dan diskusi mendalam melalui pertemuan informal antara peneliti dan para pengusaha tapioka menunjukkan bahwa para pengusaha tapioka belum memiliki wawasan yang cukup tentang manajemen usaha (produksi dan pemasaran) tepung tapioka. Mereka selama ini hanya memasarkan bahan setengah jadi yaitu endapan ketela pohon yang sudah mengering langsung dijual atau dipasarkan ke para tengkulak. Rudi mengatakan "selama ini yang kami jual adalah endapan ketala pohon yang sebelumnya sudah dikeringkan melalui sinar matahari (Wawancara, 22 Juli 2017).”

Hal ini selarasdengan hasil penelitian Nugraheni dan Subaweh (2011) juga menyatakan bahwa sumber daya manusia masih menjadi masalah pokok dalam upaya pengembangan UMKM.Tentu, minimnya keterampilan SDM seperti tersebut juga berdampak langsung pada stagnasi usaha.

Karena itu, kemampaun SDM dalam mengembangkan usaha tepung tapioka di Desa Bulu wajib diperkuat sehingga usaha tersebut menjadi lebih maju dan berdaya saing. Kemampuan dan kompetensi sumber daya manusia memiliki pengaruh signifikan terhadap upaya pengembangan UMKM. Hal ini konsisten dengan pernyataan teoretik Ardiana, Brahmayanti, dan Subaedi (2010) yang menyatakan bahwa kompetensi SDM UKM memiliki hubungan yang signifikan terhadap kinerja UKM. Dengan kata lain, baik atau buruknya kinerja suatu UMKM tergantung pada pelaku atau sumber daya manusia UMKM tersebut. Oleh sebab itu, upaya peningkatan kualitas sumber daya manusia dalam rangka pengembangan UMKM merupakan sebuah keharusan. Hal ini mengingat bahwa pengelolaan sumber daya manusia yang dapat meningkatkan kinerja berujung pada produktivitas perusahaan (Dhania dan Hervi, t.t). Keterbatasan SDM usaha kecil baik dari segi pendidikan formal maupun pengetahuan dan keterampilannya sangat berpengaruh terhadap manajemen pengelolaan usahanya, sehingga usaha tersebut sulit untuk berkembang dengan optimal (Hafsah dalam Raselawati, 20 I I).

Masalah ini mendorong pemerintah melalui Rencana Strategis Kementerian Koperasi dan UKM tahun 2015-2019 untuk meningkatkan kualitas sumber daya manusia melalui penguatan kebijakan kewirausahaan yang mencakup pola pengembangan kewirausahaan, penataan kurikulum 


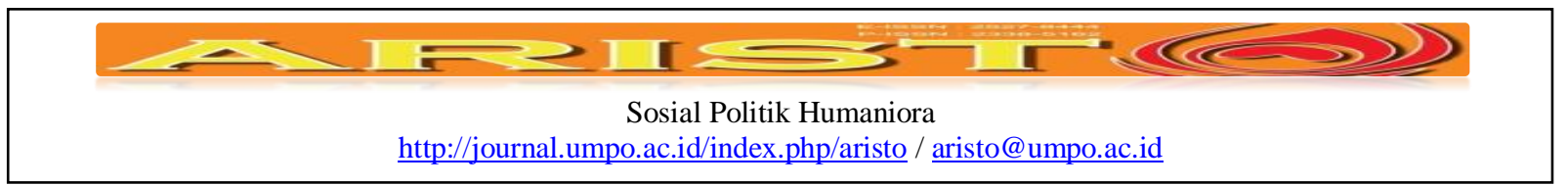

kewirausahaan di lembaga pendidikan formal, serta perluasan dukungan khususnya bagi wirausaha berbasis teknologi (technopreneurs), dan peningkatan akses ke pelatihan dan layanan pendampingan usaha. Upaya pemerintah dalam meningkatkan sumber daya manusia tersebut mencerminkan bahwa sumber daya manusia memiliki peran yang strategis dalam pengembangan UMKM.

\section{Keterbatasan modal usaha}

Hasil penelitian ini menunjukkan bahwapengusaha Pati Tepung Tapioka di Kediri memiliki keterbatasan modal usaha sehingga berimplikasi terhadap lambatnya pengembangan usaha tersebut. Berdasarkan hasil diskusi mendalam kami di lokasi penelitian menyimpulkan bahwa selama ini para pengusaha tepung tapioka tidak memiliki modal (uang) untuk mendukung produksi dan pemasaran hasil usaha. Modal yang mereka gunakan untuk usaha adalah modal pinjaman dari para tengkulak tepung di desa tersebut.

Temuan tersebut selaras dengan hasil kajian dilakukan oleh Syariifah (2015) yang mengungkapkan bahwa masalah yang paling dominan yang dihadapi pelaku UMKM adalah masalah modal usaha. Kemudian, Badan Pengkajian dan Pengembangan Kebijakan Perdagangan Kementerian Perdagangan (2013) pun mengakui bahwa masalah yang hingga kini masih menjadi kendala dalam pengembangan usaha UMKM adalah keterbatasan modal yang dimiliki karena terbatasnya akses sumber permodalan dari UMKM dan sulitnya UMKM memenuhi persyaratan yang ditetapkan.

Keterbatsan modal dalam pengembangan usaha hakikatnya merupakan persoalan klasik yang selalu melekat pada suatu usaha atau bisnis. Harahap (2015) dalam jurnal berjudul Analisis Hukum Pemberian Kredit kepada Us'aha Kecil di Provinsi Sumatera Utara juga menyebutkan bahwa keterbatasan sumberdaya yang dimiliki UMKM khususnya modal dan teknologi merupakan kendala klasik yang selama ini dihadapi UMKM dalam memperluas kegiatan bisnisnyaiusahanya.

\section{Permainan tengkulak ketela pohon}

Masalah lain yang ditemukan penelitian ini adalah adanya permainan tengkulak ketelapohon (bahan baku tepung pati) yang merugikan pengusaha tepung tapioka di Desa Bulu Kediri. Penelitian ini mengungkapkan bahwaketerbatasan dan sulitnya pengusaha Pati Tepung Tapioka di Kediri dalam mengakses sumber permodalan mendesak para pengusaha tersebut untuk mencari jalan pintas menggunakan jasa pinjaman kepada tengkulak. Upaya tengkulak dalam menyediakan modal bagi para pengusaha kecil hakikatnya sudah umum terjadi.

Tengkulak memiliki posisi yang strategis dalam menghubungkan antara pengusaha kecil dengan pembeli. Bahkan, tengkulak dalam beberapa kasus mampu memberi dampak positif terhadap pengusaha kecil tersebut. Azizah (2016) menemukan bahwa tengkulak yang memiliki sisi positif yaitu tengkulak yang memiliki peran sebagai pengumpul, pembeli, 


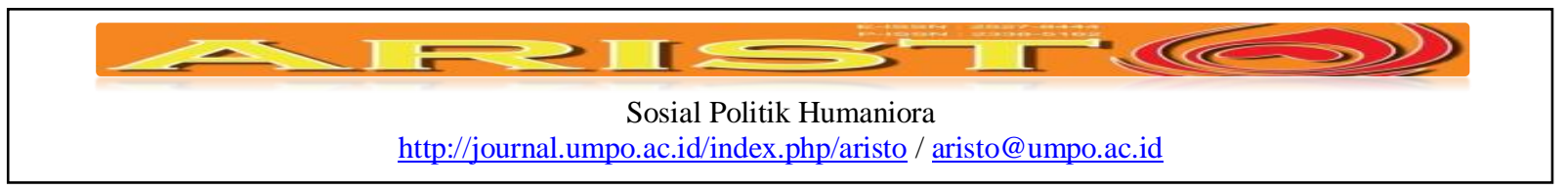

penghubung, dan pemasar. Temuan tersebut menunjukkan bahwa tengkulak mampu membantu para pengusaha kecil untuk mendistibusikan barang yang hendak diperdagangkan.

Namun di sisi lain, keberadaan tengkulak justru merugikan para pengusaha kecil tersebut. Pada suatu kasus, Amy dan Adiba (2010) mengungkap kerugian seorang nelayan yang disebabkan oleh tengkulak:

"Pada awalnya tengkulak memberi modal Rp 15.000.000,00 yang berupa perahu beserta alat-alat dan perlengkapan untuk menangkap ikan pada nelayan. Tengkulak menganggap Rp 15.000.000,00 tersebut sebagai hutang. Nelayan dalam pelunasan hutang yang Rp 15.000,000,00 tidak diizinkan untuk membayar dengan sistem cicilan. Jadi nelayan harus membayar kontan Rp 15.000.000,00 jika ingin terbebas dari hutang tersebut. Permasalahan pun muncul ketika nelayan harus menjual ikan hasil tangkapannya kepada tengkulak tersebut dengan harga jauh lebih murah dari harga pasar. Kasus yang pernah terjadi yaitu harga ikan layur dipasar Rp 23.000,00/kg, tengkulak membeli dari nelayan Grajagan seharga Rp 15.000,00/kg. Bahkan pernah terjadi ketika harga ikan lemuru dipasaran 10.000/kg, tengkulak membeli dengan harga Rp 1.500,00/kg saja."

Berdasarkan temuan di atas menunjukkan bahwa tengkulak bersikap sewenang-wenang sehingga mengakibatkan kerugian terhadap nelayan. Tim Komunikasi Kementerian Koordinator Bidang Perekonomian (2016) dalam naskah Jumpa Pers berjudul Sinergi Aksi untuk Ekonomi Rakyat: Tingkatkan Tawar Petani-Nelayan juga menyebutkan bahwa kondisi demikian mengkibatkan keuntungan terbesar justru dinikmati pedagang perantara atau tengkulak.

Hasil penelitian ini pun memiliki kedekatan kasus dengan kasus yang diangkat di atas. Para tengkulak ketela pohon membeli ketela dengan harga yang sangat murah kepada petani tetapi menjualnya kembali kepada pembeli atau penampung tepung dengan harga yang lebih mahal. Oleh sebab itu, sebagaimana hasil penelitian ini, meskipun di satu sisi tengkulak mampu menjadi alternatif atas keterbatasan pengusaha dalam mengakses modal usaha namun di sisi lainnya justru menjadi bumerang yang berakibat pada tersanderanya pengembangan usaha Pati Tepung Tapioka di Kediri.

\section{Permainan pengusaha penampung tepung}

Hasil penelitian ini juga menunjukkan bahwa penjualan tepung melalui proses rantai distribusi yang cukup panjang. Ketela pohon yang dibeli langsung dari petani oleh tengkulak akan dijual kepada pengusaha penampung atau pengepul tepung. Pengusaha pengepul tepung dalam rantai distribusi ini memiliki peran penting untuk mengatur harga karena selain memiliki modal yang besar juga memiliki jaringan pasar yang luas.

Sejalan dengan temuan kami tersebut, Rahmawati (1999) juga mengungkap bahwa posisi pengepul dalam pemasaran kuat karena memiliki sumber informasi yang lebih banyak yaitu 


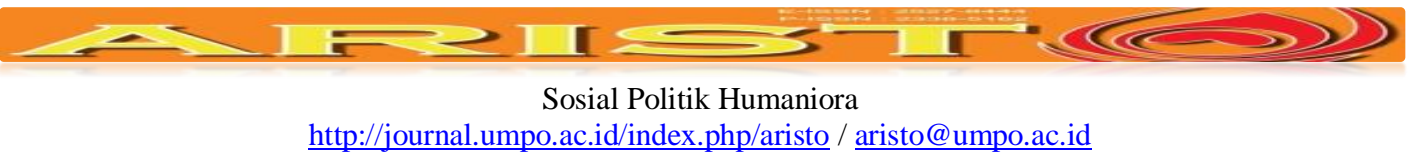

dari pengecer dan grosir untuk pasar dalam negeri serta eksportir untuk pasar luar negeri. Selanjutnya, Saptana dan Sartika (2014) menemukan bahwa dari berbagai jalur rantai pasok posisi pedagang pengumpul dan pengepul adalah yang paling strategis, karena pelaku inilah yang memiliki akses ke peternak dan akses ke berbagai tujuan pasar dengan baik. Panjangnya rantai distribusi ini secara tidak langsung merugikan para petani. Walaupun harga akan bergerak sesuai tarik ulur permintaan dan penawaran barang, selisih keuntungan akan lebih banyak dinikmati tengkulak/pengepul (Fuad, Aenuroik, dan Rosyid, 2015).

Kuatnya posisi daya tawar tersebut berpotensi membuka celah bagi pengepul untuk mempermainkan harga seenaknya.

Ralunan dan Widodo (2015) menemukan bahwa tidak jarang pihak pengepul atau juragan memainkan harga tembakau guna memaksimalkan keuntungan sendiri tanpa memperhitungkan kerugian yang harus ditanggung oleh petani. Temuan tersebut mempekuat hasil penelitian ini yang menunjukkan bahwa permainan pengusaha penampung atau pengepul secara tidak langsung berkontribusi terhadap kerugian yang dialami petani.Dengan demikian, petani sebagai produsen justru terkesan sangat lemah. Prihatini (2014) juga menemukan bahwa kebutuhan modal yang masih menggantungkan kepada pedagang pengepul sebagai pemilik modal sangat merugikan petani karena tidak bisa menentukan harga yang diinginkan petani bahkan yang terjadi harga biji kopi ditingkat petani jauh di bawah harga pasar. Rendahnya harga jual di tingkat petani berimbas pada rendahnya keuntungan yang diperoleh sehingga potensi penguatan modal usaha juga lemah.

Temuan-temuan penelitian lain yang dijelaskan di atas juga berlangsung secara masif di usaha tepung tapioka di desa bulu kediri. Relasi antara pengusaha tepung tapioka dan para pengepul dinilai tidak mencerminkan relasi berkeadilan. Pasalnya, para pengepul tepung memberi modal usaha kepada para pengusaha tepung untuk menjalankan usahanya. Kemudian hasil usaha para pengusaha tepung tapioka harus dijual ke pengepul penyedia modal tersebut dengan harga murah. Pada kasus ini, posisi pengusaha tepung tapioka adalah seperti buruh pada usahanya sendiri, sedangkan yang menjadi bos dalam usaha mereka adalah para pengepul tepung. 


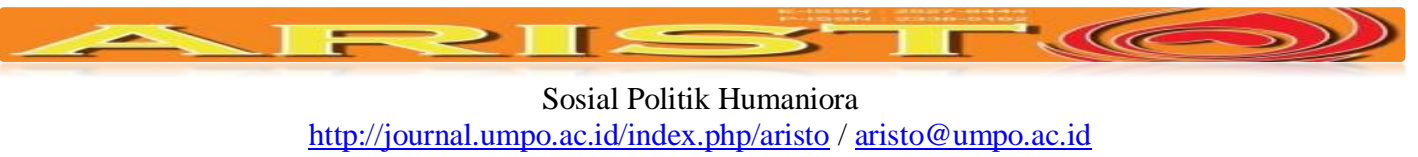

\section{Model Manajemen UMKM: Usaha Pati epung Tapioka}

\section{Pembentukan lembaga usaha (Kelompok Usaha)}

Pembentukan kelompok usaha oleh pengusaha Pati Tepung Tapioka di Kediri merupakan 1.angkah awal untuk mengembangkan UMKM tersebut. Keterlibatan jaringan kelompok sebagai basis dalam jaringan usaha diharapkan dapat mengatasi pennasalahan permodalan dan kedisiplinan pelaku usaha. Demikian pula hambatan penyediaan bahan baku dan proses produksi serta pemasaran dapat diatasi dengan pengelompokan tugas (difersifikasi) dari bagian bahan baku dan proses produksi sampai pemasarannya (Daulay, 2014).

Pelembagaan usaha menjadi sebuah kelompok usaha tidak hanya dalam rangka mengatasi persoalan-persoalan yang dihadapi UMKM saja, melainkan juga berkaitan dengan pengembangan dan pemberdayaan pelaku usaha. Indrika (2013) dalam skripsi berjudul Pemberdayaan Masyarakat melalui Program Kelompok Usaha Bersama (KUBE) Tanjung dalam Meningkatkan Kualitas Hidup (Studi di Desa Wonokerso Temba•k Temanggung) menemukan bahwa pelaksanaan pembelajaran program KUBE Tanjung menggunakan pendekatan partisipatif, yaitu strategi yang mengikutkan anggota dalam manajemen kegiatan mulai dari perencanaan sampai pada evaluasi untuk mencapai tujuan bersama yakni meningkatkan kualitas pengetahuan dan keterampilan anggota KUBE Tanjung di Desa Wonokerso. Berdasarkan temuan tersebut, usaha yang dijalankan secara berkelompok tidak hanya berkaitan dengan pengembangan usaha namun juga berkontribusi terhadap peningkatan kemampuan dan keterampilan para anggotanya.

Namun demikian, pembentukan kelompok usaha harus didasarkan pada kesamaan visi dalam mengembangkan usaha. Pada suatu kasus, kelompok usaha justru tidak berjalan secara efektif karena tidak adanya satu kesatuan visi maupun hal-hal yang bersifat teknis. Hermanto dan Swastika (2011) dalam jurnal berjudul Penguatan Kelom_pok Tani: Langkah Awal Peningkatan Kesejahteraan Petani menemukan bahwa secara umum kelompok tani di Kabupaten Bangka Tengah dapat dikatakan belurn dapat berperan dan berfungsi sebagai organisasi usaha tani yang bertujuan untuk mengembangkan usaha, meningkatkan inovasi, dan perluasan pemasaran. Longgarnya eksistensi kelompok tani ini karena beberapa alasan, diantaranya yaitu belum ada visi kepentingan yang sama diantara anggota, berlum ada kader tani yang berdedikasi dalam menggerakkan petani lainnya, dan aspek leadership yang masih kurang. 


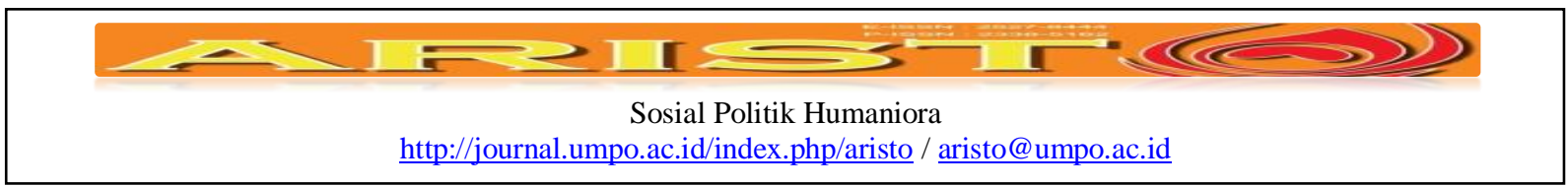

Berdasarkan keterangan-keterangan di atas, pembentukan kelompok usaha melekat erat dengan dampak positif maupun negatif. Namun demikian, kelompok usaha yang dikelola secara profesional mamiliki pengaruh positif terhadap pemberdayaan pelaku usaha maupun terhadap pengembangan usaha itu sendiri. Oleh sebab itu, pendampingan pembentukan kelompok usaha Pati Tepung Tapioka di Kediri merupakan podium untuk menyamakan visi dan persepsi tentang pengembangan usaha agar menjadi lebih produktif sehingga terhindar dari hal-hal buruk yang dikhawatirkan menghambat pengembangan usaha. Melalui kelompok usaha, para pengusaha terlindungi dari segi administrasi, pengusaha dapat dengan mudah mendapatkan pinjaman modal untuk mengembangkan usaha, dan pengusaha dapat menjadikan organisasi usaha sebagai sarana komunikasi dan interaksi antara pengusaha, pemerintah, dan pasar.

\section{Memperkuat jaringan kerjasama antara Kelompok Usaha, Pasar, dan Petani Ketela Pohon}

Pembentukan kelompok usaha membuka peluang terhadap penguatan jaringan atau kemitraan dengan berbagai pihak. Zakaria (t.t) dalam jurnal berjudul Penguatan Kelembagaan Kelompok Tani Kunci Kesejahteraan Petani menyatakan bahwa upaya meningkatkan daya saing dan kesejahteraan petani ditempuh melalui pemberdayaan organisasi ekonomi rakyat (petani) yang dilakukan sungguh-sungguh, konsisten, dan berkesinambungan dalam tiga fase mulai dari pemberdayaan kelembagaan, pengembangan jaring kemitraan bisnis hingga ke fase peningkatan dasa saing. Pernyataan tesebut secara eksplisit mengungkapkan bahwa pengembangan jaringan kerjasama atau kemitraan merupakan tahapan penting untuk mengembangankan usaha khususnya meningkatkan daya saing.

Memperkuat jaringan kemitraan antara kelompok usaha dengan berbagai pihak memiliki dampak positif yang cukup signifikan terhadap pengembangan dan kemandirian usaha. Nawawi (2016) dalam jurnal berjudul Kemitraan di Sektor Perikanan Tangkap: Strategi untuk Kelangsungan Usaha dan Pekerjaan menemukan bahwa pengembangan kemitraan dan pemberdayaan masyarakat nelayan merupakan salah satu cara yang dapat ditempuh untuk menjamin keberlangsungan usaha dan pekerjaan di sektor perikanan serta mendukung peningkatan ekonomi dan sosial penduduk yang lebih luas hingga bahkan melepas ketergantungan nelayan terhadap lembaga permodalan tradisional. Temuan ini menunjukkan bahwa kuatnya jaringan kerjasama berkontribusi terhadap keberlangsungan usaha. Selain itu, 


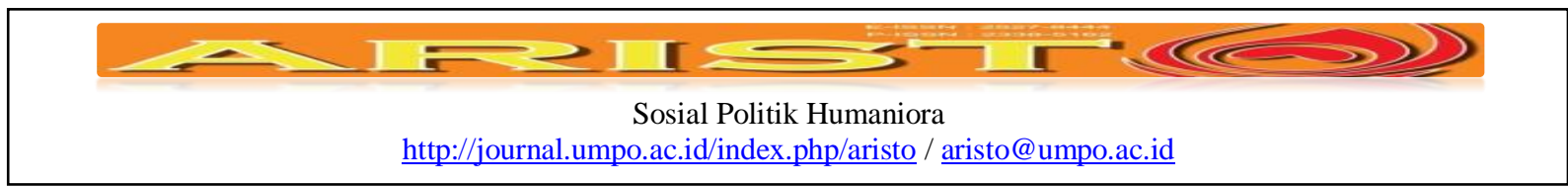

kemampuan melepaskan diri dari lembaga permodalan tradisional seperti tengkulak merupakan langkah penting khususnya bagi pelaku usaha Pati Tepung Tapioka. Hal ini mengingat bahwa melalui jaringan kemitraan, kelompok usaha memiliki daya tawar yang tinggi untuk memutus rantai bisnis yang tidak sehat tersebut.

\section{Memperkuat modal usaha melalui sistem simpan pinjam}

Simpan pinjam adalah simpanan yang dikumpulkan bersama dan dipinjamkan kepada anggota yang memerlukan pinjaman dalam rangka kepentingan produktif. Koperasi atau Unit Simpan Pinjam melindungi anggotanya dari rentenir dan pemerintah berusaha memperbesar usaha koperasi dengan memberikan pinjaman modal kepada koperasi, sehingga anggota koperasi terhindar dari tangan rentenir melalui pinjaman dari koperasi dengan bunga-bunga yang ringan (Budiman, t.t). Hal ini merupakan kekuatan atau modal penting untuk mengurangi atau bahkan meniadakan ketergantungan para pengusaha dari jeratan tengkulak khususnya bagi para pengusaha Pati Tepung Tapioka di Kediri.

Farhana (2010) dalam skripsi berjudul Pemberdayaan Masyarakat melalui Simpan Pinjam (Studi Kasus: Program Simpan Pinjarn di BlvIT Khairul Ummah Leuwi. LiangBogor)menemukan bahwa ternyata dengan adanya BMT Khairul Ummah melalui program simpan pinjam menjadi salah satu alternatif bagi para usaha kecil maupun menengah dalam segi perbaikan ekonomi dan peningkatan usaha mereka. Pengembangan usaha yang berdampak terhadap peningkatan pendapatan masyarakat melalui sistem simpan pinjam juga diungkap oleh Iyan dan Yuliani (t.t) dalam jurnal berjudul Peran Kredit Koperasi Simpan Pinjam terhadap Peningkatan Pendapatan dan Usaha Anggotanya di Kecamatan Tembilahan Kabupaten Indragiri Hilir menuliskan bahwa pemberian kredit oleh Koperasi Simpan Pinjam (KSP) di Kecamatan Tembilahan Kabupaten Indragiri Hilir kepada anggotanya cukup berarti dalam meningkatkan pendapatan dan omset usaha anggotanya.

Berdasarkan dua temuan penting di atas, sistem simpan pinjam memiliki manfaat yang substantif terhadap kebutuhan pengusaha kecil maupun menengah. Hal ini sekaligus merupakan jawaban atas persoalan permodalan pengusaha Pati Tepung Tapioka di Kediri yang bergantung kepada tengkulak yang hakikatnya menghambat kemajuan usaha para pengusaha. Dengan demikian, sistem simpan pinjam sebagai sumber penguatan modal bagi pengusaha Pati Tepung Tapioka adalah alternatif yang solutif dalam mengembangkan usaha tersebut. 


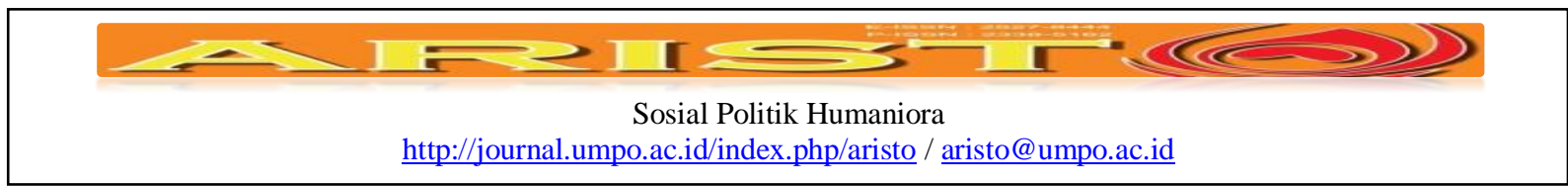

Berdasarkan penjelasan di atas menunjukkan bahwa model manajemen pengembangan usaha Pati Tepung Tapioka mengacu pada tiga unsur penting yaitu pembentukan lembaga usaha, penguatan kemitraan, dan penguatan modal usaha. Sinergitas ketiga unsur tersebut merupakan jawaban atas persoalan-persoalan yang dihadapi para pengusaha Pati Tepung Tapioka di Kediri. Pertama, berdasarkan deskripsi di atas, pembentukan kelompok usaha akan mendorong para pengusaha untuk mengelola bisnisnya secara profesional sehingga berdampak terhadap pengembangan usaha. Kedua, melalui kelompok usaha, para pengusaha memiliki potensi besar untuk memperkuat jaringan kemitraan dengan petani, pasar, dan pemerintah. Bahkan, hal ini dapat memperpendek rantai distribusi yang selama ini merugikan para petani maupun pengusaha kecil. Ketiga, pembentukan kelompok usaha di sisi lainnya juga akan berimplikasi terhadap penguatan modal usaha melalui sistem simpan pinjam. Selain itu, kuatnya jaringan kemitraan selanjutnya akan mempermudah dan memperluas akses bagi para pengusaha untuk memperkuat modal usaha melalui lembaga perbankan maupun nonperbankan.

\section{Kesimpulan}

Pengembangan Usaha Pati Tepung Tapioka di Kediri merupakan agenda jangka panjang untuk meningkatkan kualitas hidup masyarakat khususnya para pengusaha kecil tepung tapioka tersebut. Selain itu, dalam skala yang lebih luas, upaya pengembangan usaha pati tepung tapioka merupakan upaya untuk menyediakan tepung bagi kebutuhan nasional. Berdasarkan hasil penelitian ini ditemukan bahwa pengembangan usaha pati tepung tapioka dihadapkan dengan kompleksitas permasalahan. Adapun permasalahanpermasalahan tersebut diantaranya adalah belum terbentuknya lembaga usaha, minimnya keterampilan SDM dalam mengembangkan usaha, terbatasnya modal usaha, dan permainan tengkulak dan pengusaha penampung tepung yang memberi dampak negatif terhadap petani maupun pelaku UMKM. Namun demikian, Tim merumuskan langkah solutif untuk meminimalisasi kompleksitas permasalahan di atas. Adapun langkahlangkah tersebut diataranya adalah pembentukan lembaga usaha, penguatan jaringan kemitraan antara kelompok usaha, pasar, petani, dan pemerintah, serta penguatan modal usaha melalui sistem simpan pinjam. 


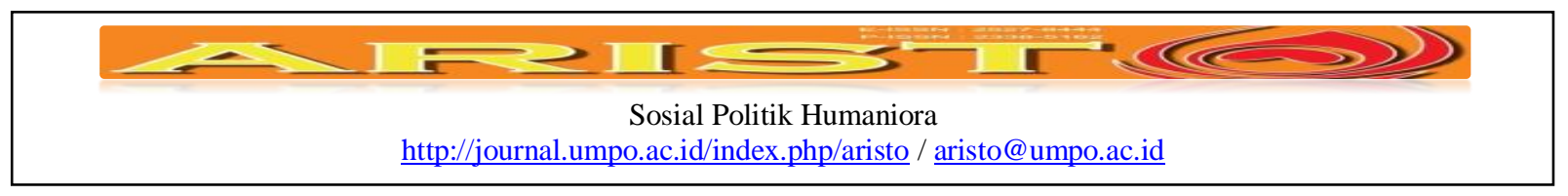

\section{Daftar Pustaka}

Afifah, R. Z., \& Setiawan, A. H. (2012). Analisis Bantuan Modal dan Kredit Bagi Kelompok Pelaku Usaha Mikro Oleh Dinas Koperusi dan UMKM Kota Semarang (Studi Kasus: KPUM di Kelurahan Pekunden, Kecamatan Semarang Tengah) (Doctoral dissertation, Fakultas Ekonomika dan Bisnis).

Amy dan Adiba (2010) dalam karya tulis ihniah berjudul Membebaskan Nelayan dari Jeratan Tengkulak dari Segi Permodalan Melalui Program Pernberdayaan Kemandirian Nelayan dengan KUD Syariah (Studi Kasus: Nelayan Desa Grajagan, Kecamatan Purwoharjo, Kabupaten Banyuwangi)

Ardiana, I. D. K. R., Brahmayanti, I. A., \& Subaedi, S. (2010). Kompetensi SDM UKM dan Pengaruhnya Terhadap Kinerja UKM di Surabaya. Jurnal manajemen dan Kewirausahaan, 12(1), pp-42.

Asiati, D., \& Nawawi, N. F. N. (2017). KEMITRAAN DI SEKTOR PERIKANAN TANGKAP: STRA UNTUK KELANGSUNGAN USAHA DAN PEKERJAAN. Jurnal Kependudukan Indonesia, 1(2), 103-118.

Azizah, E. N. (2016). Peran Positif Tengkulak dalam Pemasaran Buah Manggis Petani: Studi Jaringan Sosial Tengkulak di Desa Karacak, Kecamatan Leuwiliang, Kabupaten Bogor. Indonesian Journal of Sociology and Education Policy, 1(1), 80-102.

Creswell, J. W. (2013). Research design: Qualitative, quantitative, and mixed methods approaches. Sage publications.

Daulay, R. (2014). STRATEGI JARINGAN USAHA UNTUK MENINGKATKANPENDAPATAN MASYARAKAT. JURNAL EKONOMIKAWAY, 11(12). Farhana, L. F. Peberdayaan masyarakat melalui simpan pinjam: studi kasus program simpan pinjam di BMT Khairul Ummah Lew Liang - Bogor.

Ediarno. (2015). Posisi Teori Ekonomi Bagi Hasil Didalam Perkembangan Kajian Ekonomi Politik. http://ekonomi-bagi-hasil.com/wp-content/uploads/2015/05/POSISI-TEORIEKONOMI-BAGI-HASIL-.pdf

Fitriati Rachma. (2015). Menguak Daya Saing UMKM Industri Kreatif: Sebuah Riset Tindakan Berbasis Soft Systems Methodology. Jakara: Buku Obor. 


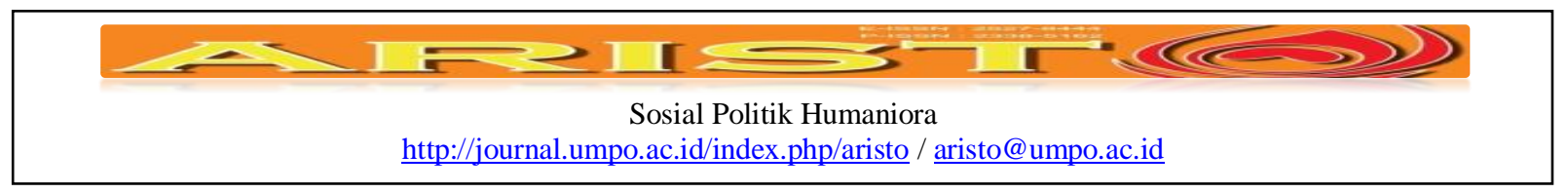

Fitrotin, U., Hastuti, S., \& Arif, S. (2006). Teknologi Pengolahan Singkong Terpadu Skala Rumah Tangga di Pedesaan. In Prosiding Seminar Nasional Ketahanan Pangan di Mataram Nusa Tenggara Barat.

Fuad, 1. Z., Aenurofik, A., \& Rosyid, A. (2015). BELENGGU TENGKULAK ATAS PETANI PEMBUDIDAYA LELE: Relasi Patron-Klien Budidaya Lele Di Wonotunggal Jawa Tengah. JURNAL HUKU ISLAM, 13(2), 88-98.

Hadi, D. P. (2015). STRATEGI PEMBERDAYAAN MASYARAKAT PADA USAHA KECIL DAN MENENGAH BERBASIS SUMBER DAYA LOKAL DALAM RANGKA MILLENIUM DEVELOPMENT GOALS 2015 (STUDI KASUS DI PNPM-MP KABUPATEN KENDAL). C/V/S, 5(1/Januari).

Hadipranata, A. F. (1999). PENGARUH PEMBENTUKAN KELOMPOK (TEAM BUILDING) IERHADAP ETOS KERJA DAN KONTRIBUSINYA BAGI PRODUKTIVITAS KERJA INSANI. Jurnal Psikologi, 26(1), 18-28.

Hadiwijoyo, R. (2014). Model Pengembangan Kawasan Industri Benvawasan Lingkungan dengan Tinjauan Penggunaan Energi di Kawasan Industri Krakatau Cilegon (Doctoral dissertation, Program Doktor Ilmu Lingkungan).

Handoko Yunus. (2013). Pemikiran Ekonomi Politik Taylor, Smith, Marx dan Keynes. Jurnal JIBEKA Volume 7 No 2, 64 - 70.

Harahap, A. J. (2015). Analisis Hukum Pemberian Kredit kepada Usaha Kecil di Provinsi Sumatera Utara. JUPIIS: Jurnal Pendidikan Ilmu-ilmu Sosial , 7(2), 125-131.

Indrika (2013) dalam skripsi berjudul Pemberdayaan Masyarakat melalui Program Kelompok Usaha Bersama (KUBE) Tanjung dalam Meningkatkan Kualitas Hidup (Studi di Desa Wonokerso Tembarak Temanggung)

Iyan, R. Y. (2013). Peran Kredit Koperasi Simpan Pinjam Terhadap Peningkatan Pendapatan Dan Usaha Anggotanya Di Kecamatan Tembilahan Kabupaten Indragiri Hilir. Ju••al Ekonomi, 19(04).

Kurniawan, F. D., \& Fauziah, L. (2014). Pemberdayaan Usaha Mikro Kecil dan Menengah (UMKM) dalam Penanggulangan Kemiskinan. JKMP (Jurnal Kehijakan dan Manajemen Publik), 2(2), 165-176. 


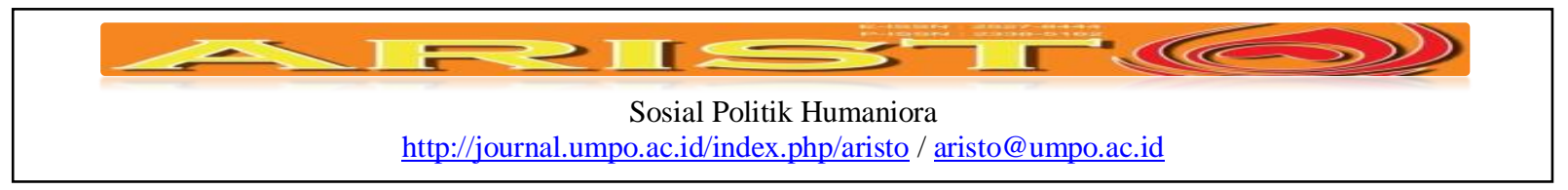

Lie, L., \& Kis, I. (2008). MENDORONG PERTUMBUHAN USAHA MIKRO, KECIL, DAN MENENGAH DENGAN PROGRAM-PROGRAM BERBASIS KNOWLEDGE MANAGEMENT. Dinamika Ekonomi, 1(1).

Mongid Abdul dan Notodihardjo Soegeng FX. (2011). Pengembangan Daya Saing UMKM di Malaysia dan Singapura: Sebuah Komparasi. Jurnal Keuangan dan perbankan Volume 15 No. 2, 243-253.

Nugraheni, P., \& Subaweh, I. (2011). Pengaruh Penerapan Standar Akuntansi Pemerintahan Terhadap Kualitas Laporan Keuangan. Jurnal Ilmiah Ekonomi Bisnis, 13(1).

Prihatini, D. VALUE CHAIN ANALYSIS (ANALISIS RANTAI PASOK) UNTUK PENINGKATAN PENDAPATAN PETANI KOPI PADA INDUSTRI KOPI BIJI RAKYAT DI KABUPATEN JEMBER.

Pujiono, A. (2010). Dampak Zakat terhadap Pengentasan Kemiskinan melalui Program Zakat Produktif dan berbasis pada Pemberdayaan Keluarga Swadaya Masyarakat Miskin. Jurnal Ekbisi, 5(1), $1-20$.

Rahman, M., \& Widodo, S. (2015). DAMPAK KEBIJAKAN ANTI TEMI3AKAU I LRHADAP STRATEGI NAFKAH PETANI TEMBAKAU MADURA (Studi Kasus Desa Panaguan Kecamatan Proppo Pamekasan). Media Trend, 10(2), 114-124.

Rahmawati, E. (1999). Analisis Saluran Pemasaran Manggis (Studi Kasus Desa Puspahiang, Kecamatan Salawu, Kabupaten Tasikmalaya, Jawa Barat.

Rapini, T., Farida, U., \& Adji, S. (2016). MENUJU KEBERHASILAN PEMBINAAN USAHA KECIL DAN MENENGAH DI KABUPATEN PONOROGO. In PROSIDING SEMINAR NASIONAL HASIL-HASIL PENELITIAN 2016: BIDANG AGALIA ISLAM BUDAYA, EKONO14 SOSIAL HUMANIORA, TEKNOLOGI, KESEHATAN, DAN PENDIDIKAN (pp. 103-112). UNIVERSITAS MUHAMN4ADIYAH PONOROGO.

Resalawati, A. (2011). Pengaruh perkembangan usaha kecil menengah terhadap pertumbuhan ekonomi pada sektor UKM di Indonesia.

Saptana, S., \&Sartika, T. (2014). Manajemen rantai pasok komoditas telur ayam kampung. Jurnal Manajemen \& Agribi,snis, 11(1), 1-11. 


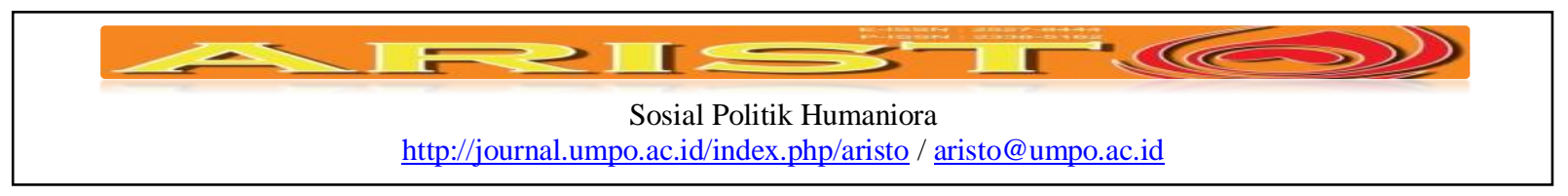

Sari Resmi Yunita dkk. (2015). Pemetaan dan Strategi Peningkatan Daya Saing UMKM dalam Menghadapi MEA 2015 dan Pasca MEA 2025. Working Paper Bank Indonesia. http://www.bi.go.id/id/umkm/penelitian/nasional/kajian/Documents

Sarwoko, E. (2009). ANALISIS PERANAN KOPERASI SIMPAN PINJAM/UNIT SIMPAN PINJAM DALAM UPAYA PENGEMBANGAN UMKM DI KABUPATEN MALANG. Jurnal Ekonomi Modernisasi, 5(3), 172-188.

Simon Vaut dkk. (2014). Ekonomi dan Sosial Demokrasi. Diterjemahkan oleh: Dr. Ivan. A. Hadar. Jakarta: Friedrich-Ebert-Stiftung Kantor Perwakilan Indonesia.

Sulistyo, H., \& Adiatma, A. (2011). Model optimalisai kemitraan usaha kecil menengah dan badan usaha milik negara melalui program kemitraan dan bina lingkungan untuk meningkatkan kinerja. Journal IPTEK, 5(2), 25-40.

Surjaningsih Ndari, Utari Diah, dan Trisnanto Budi. (2012). Dampak Kebijakan Fiskal terhadap Output Dan Inflasi. Buletin Ekonomi Moneter dan Perbankan. http://www.bi.go.id/id/publikasi/jurnalekonomi/documents/259779accf9e4b709a9b933ceffbc3e3ndarisurjaningsihgadiahutaribu ditrisnanto.pdf.

Swastika, D. K. (2016). Penguatan Kelompok Tani: Langkah Awal PeningkatanKesejahteraan Petani. Analisis Kebijakan Pertanian, 9(4), 371-390. SYARIIFAH, A. (2015). Faktor-faktor yang Mempengaruhi Kemampuan Pelaku Usaha

Mikro Kecil Menengah (UMKM). Studi Pustaka.

SYARIIFAH, A. (2015). Faktor-faktor yang Mempenganfin Kemampuan Pelaku Usaha Mikro Kecil Menengah (UMKM). Studi Pustaka.

Wijana, S., Nurika, I., \& Habibah, E. (2012). Quality feasibility analysis on the tapioca flour processed from dried cassava (The effect of dried cassava origin and calcium hypochlorite concentration used). Jurnal Teknologi Pertanian, 10(2).

Zakaria, W. A. (2009, October). Penguatan kelembagaan kelompok tani kunci kesejahteraan petani. In Di dalam Makalah Seminar Nasional Peningkatan Daya Saing Agribisnis Berorientasi Kesejahteraan Petani. Bogor (Vol. 14). 